\title{
Herders and herdsmen: The remaking of pastoral livelihoods in Laikipia, Kenya
}

\author{
Kayla Yurco
}

\begin{abstract}
Pastoralists have long overlapped with wildlife in rangelands of sub-Saharan Africa. With growing recognition of the importance of wildlife outside of protected areas, conservation efforts are increasingly managed through hybrid governance activities worldwide, activities which often involve pastoralists. These efforts are especially prevalent in East African rangelands where pastoralists, livestock, and wildlife commonly overlap outside of formal protected areas. Laikipia County, Kenya, is one region renowned for abundant and diverse wildlife species sustained outside protected areas through a collective of conservation activities among private landowners and pastoral group ranches. Little research has considered pastoralists' roles in the region's conservation efforts or the ways that those efforts shape local livelihoods. Based on data from interviews, surveys, and participant observation, this article uses a case study approach to demonstrate how some of Laikipia's pastoralists are increasingly drawn into professional herding jobs with powerful landowners involved in joint commercial ranching and wildlife conservation activities. This has caused many pastoralists to shift from traditional livestock ownership in favour of livestock caretaking for other owners, with substantial implications for livelihoods. This study offers empirical evidence for the importance of considering how diversifying pastoral livelihoods entwine with hybrid conservation processes outside protected areas.
\end{abstract}

Keywords: Conservation, Herding, Livestock, Ranch, Rangeland, Wildlife

\section{Introduction}

Considerations over whether pastoralism is compatible with conservation are not new, particularly in East Africa where pastoralists have long coexisted with wildlife (Homewood and Rodgers 1984; Prins 1992; Reid et al. 2009; Butt and Turner 2012; Homewood et al. 2012). Most scholars contend that mobile pastoralism is an efficient and productive means of managing favourable ecological conditions in drylands (Davies 2008) and that pastoralism is not necessarily detrimental to wildlife conservation goals, but rather an important component of rangeland ecology in areas where wildlife reside (Fratkin 1997). Yet productive mobile pastoralism depends on functional livestock mobility, communal land tenure, and flexible governance systems that support pastoral adaptation strategies. In East Africa, decades of land tenure shifts have meant reduced mobility for pastoralists due to land fragmentation caused by privatization, expanding conservation

Correspondence: kzy110@psu.edu

Department of Geography, Pennsylvania State University, University Park, PA 16802, USA

(c) The Author(s). 2017 Open Access This article is distributed under the terms of the Creative Commons Attribution 4.0 International License (http://creativecommons.org/licenses/by/4.0/), which permits unrestricted use, distribution, and reproduction in any medium, provided you give appropriate credit to the original author(s) and the source, provide a link to the Creative Commons license, and indicate if changes were made. efforts, and increasing climatic variability, meaning that pastoralists' needs are being compromised (McCabe 2003; Boone 2005; Galvin 2009; Goldman and Riosmena 2013). As Notenbaert et al. (2012) observe, 'the policy environment in Eastern Africa has tended to be inappropriate for the proper functioning of the positive relationship between pastoralism and biodiversity conservation' (p. 9).

Given rising challenges in maintaining traditional livestock-based livelihoods, pastoralists are in transition. In East Africa, pastoralists are diversifying toward agropastoralism and agriculture as well as other wage jobs unrelated to livestock-based economies (McCabe et al. 2014). Despite the fact that many challenges associated with changing land tenure regimes involve the rise of conservation landscapes (Notenbaert et al. 2012), many pastoralists are also seeking employment opportunities within conservation areas as rangers, guides, safari drivers, and staff at tourist lodges and camps.

Such opportunities abound in and near conservation landscapes throughout East Africa. In Kenya, as in much of sub-Saharan Africa, large protected areas were

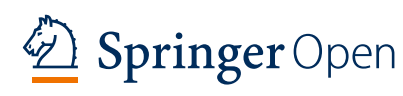


established over the last century in regions previously used by pastoralists as grazing areas (Butt et al. 2009), first as game reserves and then as national parks. More recently, following worldwide conservation shifts, there has been a substantial increase in conservation efforts beyond protected area boundaries where communities reside, work, and use resources (Bray and Velázquez 2009; King 2009). Given high incidences of wildlife on private land (Kabiri 2010), conservationists have placed special emphasis on rangelands in East Africa outside of protected areas traditionally utilized by pastoralists for grazing (Young et al. 2005; Wambuguh 2007). Such conservation efforts frequently take the form of communitybased conservation programmes, conservancies, or wildlife sanctuaries in communal lands (Goldman 2003; Igoe and Croucher 2007; Greiner 2012; Noe and Kangalawe 2015), often in or near pastoral group ranches, with many pastoralists seeking opportunities for income generation. These programmes have been celebrated and critiqued for attempting 'win-win' solutions of conservation and development.

Given this history, much of the literature on the conservation-pastoralism nexus involves specific conservation projects or discrete programmes that overlap with pastoral communities or grazing areas. These studies often consider benefits and costs to communities, attitudes toward wildlife, or property rights issues associated with wildlife conservation areas (Norton-Griffiths 1996). A recurring issue is the failure of many conservation efforts to incorporate pastoralists' local (or traditional) knowledge for participatory management. Goldman (2003), for example, discusses the ways in which conservation administrative efforts of Wildlife Management Areas in Tanzania favourably describe indigenous knowledge' yet ignore that knowledge in practice, actually prohibiting community involvement rather than encouraging participatory efforts (p. 854). Challenges involving the politics of inclusion for indigenous versus scientific knowledge are not unique to pastoralists (Agrawal 1995). But these challenges may be amplified for pastoralists who move frequently, engage simultaneously with multiple forms of conservation, and interact with multiple administrative units in multiple spaces.

With some exceptions that demonstrate how pastoralists interact differently with various types of conservation areas in the same landscapes (e.g. Butt 2011), little scholarship has considered how hybrid forms of conservation involving varied land users and land managers shape pastoral livelihoods. Hybrid governance efforts among the state, local communities, corporations, and other partners like non-governmental organizations (NGOs) are not new (Lemos and Agrawal 2006), but attention to hybrid forms of conservation governance is still needed (Armitage et al. 2012). Hybrid governance 'may hold promise' in remedying traditional, state-based conservation approaches, but their outcomes must be considered cautiously (Armitage et al. 2012, p. 253). This is especially true for pastoral regions where the range and variety of governance efforts are continually expanding and shifting (Cleaver et al. 2013).

One region where pastoralists contend with markedly diverse governance efforts related to conservation is Laikipia County of central Kenya. This region is celebrated for its abundant and diverse wildlife populations that are maintained entirely outside of formal protected areas like national parks or game reserves. Instead, wildlife populations are supported across a range of independently managed land parcels which include pastoralists' community group ranches, private commercial livestock ranches, private conservancies frequented by tourists, and research centres. While some pastoralists maintain traditional livestock-based livelihoods in community group ranches, others are increasingly being drawn into employment opportunities associated with conservation efforts in privately managed properties. As one important example, many pastoralists seek work as hired herders on private lands. This study considers the trend toward hired herding labour in Laikipia, how the trend is connected to the region's conservation efforts, and related shifts in pastoral livelihoods.

\section{Background}

Present-day land management in Laikipia is rooted in colonial-era land distribution practices (Morgan 1963) when British settlers expanded cattle ranching and agriculture in the region. In so doing, local resource control was significantly restricted and pastoralist and agricultural groups were disenfranchised or at times relocated into reserves. Land tenure challenges in Kenya's group ranches since their creation in the 1970s have been detailed extensively elsewhere, including trends toward privatization and sub-division (Galaty 1994; Mwangi 2007; Western et al. 2009; Waller 2012). Community members in Laikipia face similar land tenure challenges as other pastoralists in Kenya. Specifically, there are tensions between efforts to retain customary practices for communal governance and efforts to follow trends toward land privatization (Kaye-Zwiebel and King 2014).

The history of ethnic groups and the make-up of past and present group ranches in Laikipia are complex. For the Maasai who constitute many of the region's group ranches, it is generally recognized that the region's Laikipiak Maasai, Mukogodo hunter-gatherers, and other neighbours developed into present-day pastoralists who now label themselves Maasai (Galaty 1993; Cronk 2004). The region also includes Turkana, Samburu, and other pastoralist groups. Landowners and managers of other properties, including commercial ranches and private 
conservancies, are of African, non-African, or mixed descent. Many commercial ranches, for example, are managed by Africans of British descent. As of 2007, over half of the Laikipia region was still owned by nonAfricans (Wambuguh 2007), demonstrating that the presence of the so-called White Highlands (Morgan 1963; Carey Jones 1965) prevails today.

Indeed, the primary land use in the region is large-scale ranching under non-African ownership (Wambuguh 2007), but many landowners are diversifying within private ranches. Following global trends of conservation interest in the 1980s, many large private ranches in the region began at that time to favour wildlife conservation activities (Georgiadis et al. 2007). Some more recently developed into 'conservancies' intending to engage in livestock production alongside wildlife management, often with tourism activities (Bond 2014a). These conservancies offer intimate safari tours, promoting the experience as one much more private than can be experienced in the nation's larger game reserves and parks. Other private ranches host long-term and short-term scientists and researchers for studies and experiments related to conservation biology, rangeland ecology, wildlife management, and other similar fields. Group ranches also have begun setting aside land for conservancies and establishing lodges (Kaye-Zwiebel and King 2014), and ecotourism efforts have been bolstered recently through activities of groups like the Northern Rangelands Trust and the Naibunga Conservancy (NRT 2016). Kenya Wildlife Service, an extension of the national government, provides some support for wildlife-related research and conservation activities, but there is limited national oversight as compared to other regions in Kenya.

Laikipia County is thus a complex, 'spatially chaotic' mosaic where humans, wildlife, and livestock share land and resources among multi-use parcels (Evans and Adams 2016, p. 218). With no formal protected areas, conservation persists in Laikipia through a variety of independent and collective efforts. Landowners, land managers, and land users work to sustain diverse, often conflicting smallholder activities amidst regional conservation efforts. Some landowners prioritize goals for wildlife conservation while others prioritize livestock production, and many have adopted plans to pursue both goals in tandem. In effect, all residents take part in wildlife management (some willingly, some by virtue of overlapping with mostly unfenced wildlife habitats). As such, the region offers private landowners and land users both opportunities and costs of hosting wildlife on their lands.

With no official regional policy for managing wildlife, there is sometimes discord about management decisions between landowners and land users. Resource disparities and competing desires for land use among so many different residents have resulted in a complicated assemblage of wildlife-tolerant and wildlife-intolerant parcels (Gadd 2005). Furthermore, there is often disagreement about how to engage in sustainable livestock production alongside or in lieu of wildlife conservation, both for commercial ranches and for pastoralists in group ranches. The juxtaposition of these efforts, this article demonstrates, affects local livelihoods in complicated ways, particularly for pastoralists who find themselves involved in both commercial ranching and small-scale pastoralism.

Despite the real challenges of sustaining independently managed land parcels for a variety of human, livestock, and wildlife needs, many have declared the region a conservation success (Kinnaird and O'Brien 2012). Unlike other parts of Kenya where wildlife populations have declined, wildlife numbers in Laikipia County have actually increased in recent decades (Kinnaird and O'Brien 2012). The collective effort has been celebrated as a new paragon of conservation working to simultaneously support humans, livestock, and wildlife (Sundaresan and Riginos 2010). Resource management in Laikipia is indeed a hybrid project with many participants, and though hybrid governance efforts among the state, local communities, corporations, and other partners like NGOs are far from new (Lemos and Agrawal 2006), more empirical research on how they emerge and change is still needed (Hardin 2011).

While the region has been an important hub for conservation research and ecological research for several decades (e.g. Riginos et al. 2012), less attention has been given to conservation's role in shaping social and cultural dynamics, particularly among pastoralists in the region's many community group ranches. Scholars have documented the attitudes and activities of private landowners in the region (Wambuguh 2007), but little is known about the social and environmental impacts for the region's pastoralists from general management shifts (Kibet et al. 2016) or from specific hybrid conservation efforts.

This article posits that livelihood transitions may be particularly impactful for the pastoralists who are employed in great numbers across the region in private ranches, tourism enterprises, local conservancies, and research centres. In many cases, those jobs require pastoralists to do what they already have been doing for generations livestock husbandry - but under a new set of circumstances that involve inflexible top-down rules, fixed grazing patterns, or mandatory use of particular technologies. This shift is part of a relatively new process where 'rangeland landowners are increasingly absentee and hire third party pastoralists to manage their livestock-raising a whole new set of management issues' (Riginos et al. 2012, p. 18). While these employment opportunities present some benefits, they also present challenges.

Much of the research about pastoralists in Laikipia has been oriented toward wildlife conservation rather than 
livelihoods, considering, for example, community attitudes of wildlife (Gadd 2005; Wambuguh 2007; Sifuna 2010) and human-wildlife conflict, especially humanelephant conflicts (Thouless and Sakwa 1995; Graham et al. 2010; Bond 2014a) and conflicts with carnivores (Woodroffe et al. 2005). These studies have been helpful in showcasing how the region's communities face potentially grave challenges due to wildlife proximity and overlap. They also have been helpful for demonstrating that, despite no national parks or other formal conservation areas, residents in Laikipia face similar, if not exacerbated, wildlife-related constraints as their counterparts who live near protected areas elsewhere in East Africa.

Indeed, human-wildlife conflicts have strongly shaped the political landscape in Laikipia, one that involves pastoralists as well as more wealthy landowners of private commercial ranches and tourism ventures. Some scholars contend that, at best, pastoralists have had less economic or political capability to contend with wildliferelated challenges. At worst, they have been undermined by more powerful regional stakeholders. Evans and Adams (2016) argue, for example, that private landowners' recent plans for constructing an 'elephant fence' in Laikipia were actually rooted in desires for delineating their boundaries and denying access to pastoralist 'trespassers' (p. 222). While pastoralists often gain illegal access to grazing areas in private ranches, presiding rules in the region have since colonial times favoured individual land titles rather than traditional communal strategies used by pastoralists. Evans and Adams (2016) also argue that due to a complicated political history, 'pastoralist access to land in Laikipia had been marked by exclusion, and their use of land almost everywhere was uncertain and extra-legal' (p. 221). In the case of fencing, as with other county-wide dialogues, even if and when pastoralists were invited to negotiations, few objections could be made by pastoralists in favour of de facto access norms automatically deemed illegal. Pastoralists are thus understood by some to be marginalized in Laikipia, but perceptions differ across and even within particular communities about benefits from wildlife and from ecosystem services more generally (Gadd 2005; Kaye-Zwiebel and King 2014).

While supporters of Laikipia's conservation efforts tend to celebrate progress made to improve the livelihoods of its communities, less attention has been given to ways that pastoralists individually negotiate conservation activities within such communities through new roles and livelihoods. Specifically, more research is needed on how Laikipia's pastoralists are increasingly drawn into professional herding jobs with powerful landowners involved in joint hybrid conservation activities. The objective of this article is to demonstrate how the professionalization of pastoralism has complex ramifications on livelihoods, including positive outcomes as well as potential lost opportunities. Additionally, as little empirical research has documented how pastoralists negotiate hybrid conservation efforts, this article uses a case study approach to present evidence of pastoralists' roles in and perceptions of the region's collective hybrid governance project. As Bassett (2009) has demonstrated for pastoralists in West Africa, 'the spaces and scales of development and environmental conservation programmes often fail to match the "action spaces" of humans and other species' (p. 757). In Laikipia, it is worth questioning whether such efforts also fail to match pastoralists' action spaces. Here, conservation initiatives do highly involve pastoralists - but only within a particular brand of pastoralism that has been re-designed by the region's more powerful stakeholders. The next sections describe the Laikipia region and methodology in more detail before turning back to pastoral livelihoods.

\section{Study area}

Laikipia County encompasses an area of approximately $9,500 \mathrm{~km}^{2}$ in north-central Kenya. The land is semi-arid savanna and Acacia bushland and generally experiences two annual rainy seasons, though rainfall variability is increasing. The region is commonly acknowledged as one of Kenya's most important areas for biodiversity conservation. Wildlife abundance in the county ranks second in the nation only to the Maasai Mara National Reserve (Georgiadis et al. 2007; Kinnaird and O'Brien 2012), and wildlife diversity is considerably high (Sundaresan and Riginos 2010). As noted, for East Africa, Laikipia is unique in that there is no formally protected land held in protected areas such as national parks or game reserves (Evans and Adams 2016).

Data collection was focused on three communities in the county's central area for intensive household interviews and participant observation, including one private ranch and two adjacent community group ranches. Participants included pastoralists employed as herders for cattle, sheep, goats, or camels at the private ranch and pastoralists who kept mixed herds of cattle, goats, sheep, and camels in the community group ranches. More details are provided in the following section.

\section{Methods}

This research relies on an in-depth case study approach. Over four months of fieldwork in 2010 and one month in 2011, data regarding pastoralist livelihood shifts and perceptions were collected through 79 semi-structured household interviews with local pastoralists and six weeks of participant observation of herding practices.

In the private ranch, 39 interviews were conducted. The sample included all herding employees able and willing to participate (38 males and 1 female who was the only female herder). This sample represents nearly 
complete saturation of herders at the private ranch. In the group ranches, 40 interviews were conducted (20 with males and 20 with females). Participants were selected by a spatially stratified random sample and included participants that identified as heads of household or their spouses and who were knowledgeable of household activities. Interview questions in both types of ranches considered perceptions of environmental change, shifts in the region's land and livestock management strategies, perceived outcomes of those transitions, advantages and disadvantages of various aspects of professional herding jobs, and the sustainability of the region's management practices. Participant observation involved full days of herding with professional herders to discuss environmental and social changes, management activities, and herding strategies as they occurred.

Respondents included pastoralists engaged in traditional pastoral activities, pastoralists employed at private ranches, and pastoralists taking part in both sets of livelihood activities. In the private ranch, 21 respondents identified as Turkana (53.8\%), 13 respondents identified as Maasai (33.3\%), and 5 respondents identified as other (12.8\%). Participants of different ethnic groups lived and worked together in the private ranch and were long-time residents of Laikipia County able to speak to general trends in the region. All respondents in the two community group ranches identified as Maasai.

Additionally, over 20 unstructured key informant interviews were conducted with individuals throughout Laikipia involved in pastoral activities, rangeland managers, local officials, academics, other experts, and employees of regional ranches, research centres, conservation areas, and tour companies. These interviews focused on shifts in management regimes in the region and their perceived social and environmental effects. In addition to participant observation throughout Laikipia, these interviews help to situate the case study-specific findings within broader trends in the region. For data analysis, transcriptions of household surveys and interviews were created and coded for relevant themes, as were detailed notes from participant observation of herding and herd management practices. Findings presented here derive from analysis of the entire data set.

\section{Results and discussion}

While private ranches commonly border communal group ranches in Laikipia, livestock management efforts from one side to the other seem a world away. The irony is that many of the same individuals have been involved in these efforts on either side of the border, often at the same time. Discussed here are how differences in livestock production are driven by the region's collective conservation project and particularly by powerful actors associated with private ranches.

\section{The privatization of livestock management}

Just as there is no official conservation policy in Laikipia, there are no formal regulations for county-wide livestock management practices. In theory, this means that private landowners and community members sharing group ranch land are free to manage livestock according to their own needs. In reality, however, historical, political, and economic pressures have combined in recent years such that a particular set of norms has developed for land managers in the region to align livestock production goals with conservation efforts. Norms are predicated on regional efforts to simultaneously conserve wildlife and engage in livestock production rather than engaging in livestock management practices alone.

While some landowners of private ranches were involved in implementing, maintaining, and monitoring their lands via specific rangeland management programmes, others expressed less interest in formal programmes. One land manager of a private ranch with a long history in the region professed his view succinctly: 'we need no active management of the land.' Still others fell somewhere in between, formulating their own temporary guidelines at will rather than adopting regional plans for rangeland management. Private ranches were often engaged in multiple resource management sectors at once, involving a combination of livestock production, conservation, tourism, and research support activities. An important commonality among private ranches was that most relied on external labour, employing individuals from nearby communities as hired herders to look after cattle, sheep, goats, and/or camels on their properties.

In the private ranch considered in this study, for example, several thousand livestock and several dozen hired herders were managed among six groups. The ranch manager and employees retained use of the Swahili word boma (and its anglicized plural bomas) to describe each homestead, a term commonly used to describe a settlement of extended relatives and their livestock within a protected enclosure. These bomas, however, were composed very differently than bomas of pastoral communities outside private ranches. With specific employee roles such as 'Headman', 'Watchman', and 'Herdsman', as well as several 'Temporary Hires', bomas in the private ranches functioned as tightly controlled branches within the larger commercial ranch enterprise. Notable was the relative absence of women, as all but one employee was male and only some employees were able to invite wives or children to stay in bomas with them. Family members were not formally employed but were responsible for building and maintaining traditional shelters and fencing from thorny trees.

Hired herders lived full time on-site, working in small groups to herd and tend to livestock daily. Employees did not have any kind of share or ownership in the 
ranch's animals nor could they keep their own livestock on the property. Ordinarily, ranch managers (typically non-Africans or Africans of European descent) claimed to have exclusive control over ranch operations, including decisions over where and when to graze which animals daily and seasonally. Additionally, bomas, including their infrastructure, livestock, and employees, were moved around the property according to managers as needed in order to prevent degradation or to take part in or avoid other ongoing activities within the multi-use properties. At the time of this research, some bomas had fencing of traditional branches and were referred to as 'fixed bomas', as they were moved infrequently. Others had fencing constructed with chain-link metal. Referred to as 'mobile bomas', these were rotated more frequently. At the time of research, this structure was common to private ranches across Laikipia.

This system contrasted greatly with management in nearby group ranches, where bomas and grazing practices resembled pastoral spaces elsewhere in Kenya. In the two group ranches considered in this study, for example, bomas were organized into traditional family units with smaller groups of cattle, sheep, goats, and/or camels than in the private ranches. Grazing spaces were generally communal. In many cases, communities attempted to set up core conservation areas intended to support wildlife, optimize community-based tourism opportunities, and function as reserves for grazing during droughts. Often encouraged by community stakeholders to do so, group ranch members were incentivized to join the collective conservation project by gaining logistical and sometimes financial support for demarcating conservancy land. While some community members supported these projects, others lamented limited returns for conservation spaces.

Groups like Laikipia Wildlife Forum (LWF) have played a great role in contributing to a collective project of natural resource and livestock management in the region and in incentivizing pastoralists' support. In working to unite the area's many different land users, LWF's mission is to conserve Laikipia's wildlife and ecosystem integrity and improve the lives of its people by bringing its societies together to conserve and sustainably use the natural resources on which they depend' (LWF 2016). LWF has been recognized for formalizing the region's conservation 'vision', one intended 'to see a healthy and productive natural environment for people and wildlife for the future of Laikipia and Kenya' (LWF 2016). This vision is a good example of common rhetoric in the region regarding the promotion of conservation alongside support of livelihoods.

Importantly, groups like LWF historically developed from landowners' - rather than land users' - participation in management discussions. Founded in 1992 'in response to landowners' interest in wildlife conservation, land rights and security across the County' (LWF 2016), today, LWF still relies greatly on private landowner involvement and facilitation. Private ranch owners and other powerful stakeholders make decisions that affect county-wide resources, such as to support (or protest) individual property fences or attempts to construct Laikipia-wide fences (see Evans and Adams (2016)). Even when private landowners do not support specific county-wide conservation activities, their relative prominence in the region means that they are still directly or indirectly involved in negotiations. While members of LWF expend tremendous effort to engage with pastoralist neighbours, pastoralists report challenges for consistently obtaining equal negotiation opportunities. Pastoralist community members reported increasingly feeling pressured to join in regional conservation activities by working for multi-purpose private ranches. They felt that the success of conservation in the region was rooted not in community members' activities but in private landowners' efforts.

For community members, conservation opportunities most often took the form of hired herding labour, where pastoralists relocated temporarily or permanently to private ranches to take part in commercial ranching activities alongside private conservation efforts. Pastoralists often expressed that partnerships among stakeholders in the county ensured community development outside of their own communities for the greater good of the region rather than their own communities. While pastoralists sometimes benefited from private investments in their communities through infrastructure or specific development activities (Kinnaird and O'Brien 2012), these benefits were often at the expense of continuing livestock-based production methods. Many pastoralists felt conflicted, as they were trying not only to maintain traditional herding practices in their group ranch communities but also to work as herders for private ranches involved in conservation activities. In many cases, pastoralists gave up former traditions altogether and moved permanently to private ranches when it was too difficult to do both. Negotiating the challenges between pastoralism and conservation had significant impacts on livelihoods, which are explored further in the next section.

\section{Pastoral transitions}

Pastoralists working on the private ranch contended with strict herding conventions. Of importance to respondents was that ranch managers made all decisions independent of herders, including where and when to move herds, where and when to graze livestock, and when to treat for ticks or other diseases. While herders had decision-making roles in, for example, choosing exact routes to take to reach grazing areas prescribed by managers, they noted that this amounted to little 
autonomy. In cases where herders were resistant to managers' instructions, reasons were practical. Often herders were instructed to graze livestock in areas known for high wildlife density, for example, and herders rarely felt that the risks were worthwhile. Given that employees were animal caretakers rather than owners, herders unanimously felt that there was little incentive to risk injury or death to graze in wildlife-rich areas, even if those areas held more nutritious or abundant grasses.

As one herder expressed, 'The wages are a bit poor. We are seldom paid. It could be a bit better if our wages are increased a bit so we feel happy when we are intermingling with wild animals.' Moreover, herders acknowledged little incentive to maximize use of rangelands for sustainability or to ensure that livestock reached maximal forage and water resources. As long as livestock were relatively - but not optimally - healthy, herders often deviated from instructions whenever possible to minimize risk. When asked about watering areas for livestock, for example, employees agreed that 'there is a problem of taking the animals to take water.' One employee explained that they have to move for long distances to search for water and that it was often not worth the trouble: 'The challenge that we have, is what we have about the salary, we are not feeling well because we are being disturbed by what we are getting here.' Compromising livestock health was a conscious decision only balanced by practical need to maintain employment.

With low wages and little investment in pastoralists or herding labour, there was little incentive for hired pastoralists to maximize herding effort. Even if herders wanted to contribute great efforts, most found the labour demands simply too high. Compared to the group ranches, herd size on private ranches was much higher, and many herders noted that there were not enough employees for the commercial ranches. One long-time employee explained, 'The biggest challenge is one person holding a lot of cattle.' He added with emphasis, 'The other one is there is no relieving, you cannot be relieved if you are a herdsman, you still continue being a herdsmen until the end of your term.' This statement carried with it the sentiment that working as a herdsman offered little opportunity for advancement.

Quality of herding labour has been linked to livestock productivity and rangeland health (Turner and Hiernaux 2008). Though many land managers in Laikipia report success in restoring or maintaining rangeland health, it is potentially a missed opportunity that pastoralists do not feel incentivized to fully incorporate their knowledge and skills toward that goal. Many herders who simultaneously kept their own livestock in the group ranches while working and living on private ranches noted that they did not compromise the health of their own animals in the same way that they did on the private ranches. Other scholars have demonstrated the connections of pastoral knowledge with rangeland stewardship (Goldman 2003; Opiyo et al. 2015) and that the quality of herding labour may decrease with hired herders (Turner 1999, 2009), with detrimental effects to both livestock productivity and sustainable rangeland management (Turner and Hiernaux 2008). The irony in Laikipia is that private ranch owners are for the most part involved in conservation management programmes directed toward maximizing grassland potential for both wildlife and livestock. In theory, it would be prudent for ranch owners to take advantage of pastoralists' local knowledge and labour toward this end. Yet several land managers explained that their hiring decisions prioritized experience in a wage job over specific local knowledge or herding skills.

Instead, from the perspective of hired herders, herding was a technocratic activity, where landowners relied on technology and protocols for instructing herders on how to do their work. Landowners utilized highly mechanized infrastructure for weekly cattle 'dips' to prevent livestock from acquiring diseases, mobile bomas for ease of transport, radios assigned to boma 'headmen' to communicate herding locations throughout the day, and cell phones among long-term herders to confirm daily movements. Rather than relying on flexible resource-use patterns (Galvin 2009), herders were constrained to highly regulated movements, modes of communications, and top-down rules that rarely incorporated employees' opinions or choices. Though some herders reported that these regulations made herding 'easier', herders generally agreed that they were also a constant source of conflict among employees and managers. Herders noted the hierarchies of management and of tools to manage were more challenging than the job itself: 'Some people, you know when you are managing people, there is a big problem. Some people [herdsmen] come in shouting....' Conflicting opinions and strict rules about herding decisions were frequently cited as reasons for employee termination and for frequent 'Temporary Hires'.

Grazing strategies were not the only aspects of livestock management shifting in Laikipia due to professional herding jobs. Traditionally, boys and young unmarried men have provided herding labour for most pastoral communities in Kenya. In the private ranch involved in this study, however, the average age of hired herders was much higher at 38 years. Hired herders in most cases had families residing in the group ranches. With little leave time and low pay, many respondents found it difficult to return home often. These familial dynamics were important to both men in private ranches and women in group ranches for several reasons. First, on private ranches, men were responsible not only for herding but also for milking, labour traditionally 
reserved for women. Women in group ranches, on the other hand, were consequently responsible not only for milking but in many cases for herding labour. In households with young children or households where herding labour could not be otherwise accessed, women experienced a substantial increase in labour demands when their husbands, fathers, or brothers were away working at private ranches. In effect, many households in the group ranches functioned as female-headed households for much or all of the year. This finding resonates with the work of Karmebäck et al. (2015) and others who note that pastoral women elsewhere in Kenya are increasingly taking on more work, including grazing activities, with mixed outcomes.

Indeed, gender inequality is pronounced in Laikipia (Bond 2014b), and ongoing labour transitions may be exacerbating such tensions. Pastoral women had fewer options for employment in private ranches. Similar to the ways in which county stakeholders encouraged group ranches to establish conservation areas, female group ranch members were encouraged to establish and participate in women-led ecotourism ventures in the group ranches like lodges or co-operatives for curio sales. While these opportunities seemed promising, at the time of this research, many projects intended to be managed by and for women were not operational. By not offering women opportunities for livestock-based work, the collective conservation project in Laikipia shaped women's experiences in very particular ways. On the one hand, it compelled women to diversify their livelihoods beyond livestock outside of the home while on the other hand created more livestock-based work for them at home. Both men and women were taking on new labour demands to manage livestock in private or group ranches. While changes in household division of labour due to new forms of livelihood diversification are not unique to pastoralists in Laikipia (McCabe et al. 2014), these transitions warrant further inquiry.

Furthermore, pastoralists shared concerns about the difficulty of passing on herding knowledge and expertise to their children. Many herders who both resided on private ranches full time and kept livestock at home in the group ranches described situations where they had been unable to advise their families where and when to graze livestock during recent droughts. They felt that they were unable to impart decades of experience in the region to their children or other members of their household now taking on the responsibilities of herding. Others who recognized this or whose households could not meet labour demands sold most or all of their livestock, instead relying entirely on income from professional herding. Due to increased labour demands in two spaces, families in Laikipia often had to choose between employment in private ranches or continuing to keep livestock in the group ranches. These transitions are increasingly common for pastoralists migrating for wage work in East Africa (McCabe et al. 2014).

For many, this choice was difficult. Men and women alike recounted narratives of the histories of livestock in their families and the importance of the livelihood to their identities. One interview respondent noted of his community, 'We never stay without livestock. It is what is in our minds and, I think, in our blood. The place will benefit more [from tourism], but livestock will still be here.' This man and others felt forced into herding employment as their only viable option. On the other hand, some were keen to move away from challenges in the group ranches and preferred opportunities for employment in private ranches and their associated conservation activities.

Despite the challenges, of the 39 respondents employed at a private ranch, the majority (22) wanted to remain there indefinitely. These respondents viewed their jobs as better buffers against climate variability, particularly given increasingly common droughts in the region (Huho et al. 2010). These findings reiterate those of other studies which demonstrate increasing uncertainty about livestock-based livelihoods (McCabe et al. 2014). Pastoralists in East Africa are diversifying toward other animals such as camels (Elhadi et al. 2015) and hybrid or different breeds of livestock, shifting toward agriculture and agro-pastoralism (McCabe 2003), and seeking wage jobs outside of pastoral communities entirely (Opiyo et al. 2015; Watete et al. 2016). These jobs, including professional herding jobs, represent important opportunities and sources of cash income. Yet for Laikipia, it warrants consideration as to whether these employment lines are sustainable for the mid- to long-term future, particularly if animal-caretaking jobs fully replace animal-ownership practices. If commercial ranching operations were altered significantly through livestock disease or changes in land tenure due to the creation of a protected area in Laikipia, there may be little of traditional patterns, practices, and infrastructure to fall back upon for many of the region's pastoralists.

\section{Herders and 'herdsmen'}

On a first look, group ranches and private ranches resemble one another, with similar landscapes, similar livestock utilizing similar resources, and similar wildlife species moving through the landscape. For the region's pastoralists, however, the differences in resource governance are stark. On more than one occasion during fieldwork, employees were witnessed crossing boundaries from their homes in the group ranches to return to work on the private ranches. Many were returning from checking on their homes, their families, and their own livestock, and many had engaged in herding activities 
during their visit home. Immediately upon return to private ranches, employees would don lanyards with plastic name tags: last name, first name, and in all capital letters: 'HERDSMAN'. For others, it was 'BOMA SUPERVISOR'. The shift was not only symbolic but also a material one, where transitioning from being a herder in a group ranch to a herdsman or supervisor in a private ranch meant a different set of herding practices, a different set of pressures and responsibilities, and an altogether different livelihood.

The transition from herder to herdsman was often a fluid one. On several occasions, ranching managers instructed employees to graze livestock around the perimeter of their properties, particularly along borders with group ranches, in order to dis-incentivize group ranch members from illegally grazing livestock on private land. Hired herdsmen were asked to take part in preventing such 'stealing' while employed at the private ranches. The importance of healthy rangeland ecosystems and sustainable corridors were prioritized for wildlife purposes in many of the private ranches, and managers often patrolled these areas with employees to prevent unsanctioned grazing. During times of drought, community members lamented lack of forage in the group ranches while private ranches hosted seemingly endless healthy grasslands. While some private ranches opened small areas of their properties to pastoralists (Kibet et al. 2016), others did not, and many of those that did requested a sizable fee. The irony is that many of the employed herders working to protect the private ranch borders were then prevented from herding their own livestock in the same spaces or coerced to prevent their families from doing so during times of low forage availability.

When enrolled in the politics of land use in this way, employees were constantly negotiating their own positions as hired herdsmen on private ranches and as herders raising livestock for production and tradition on nearby group ranches. In a review of ranching and pastoralism worldwide, LaRocque (2014, pp. 77-78) differentiates the two:

Whereas herding constitutes the daily fabric of many pastoralists, it is a matter of punctual logistics for ranchers as a means to reach a grazing destination like a nearby pasture... or else to perform specific tasks like vaccinating, branding, shipping, and so on... After these events are over, people and animals resume their separate existence and return to their respective spheres of habitation.

In Laikipia, political, environmental, and social pressures coalesced such that pastoralists have little recourse but to abandon a traditional 'daily fabric' and shift to being professional herdsmen, at least in part and at least in certain spaces at certain times. As these different 'spheres of habitation' are increasingly shaped by hybrid conservation efforts involving powerful ranchers and collective groups, herders are engaged in a process of continually negotiating their roles as pastoralists and the norms of pastoralism as a livelihood.

\section{Conclusions}

The conservation paradigm in Laikipia extends resource governance beyond protected areas and traditional community-based conservation areas, functioning as a complicated hybrid effort involving numerous user groups and multiple land uses. By incorporating livestock management norms into broader plans for conservation, many of the region's powerful actors engage pastoralists in a joint project to conserve and develop the region, but doing so may actually exacerbate preexisting power inequities. While the model does offer employment opportunities, in many cases, pastoralists become dependent on and limited to the economic structure of professional herding. Pastoralists are often restricted to maintaining livelihoods as herders in the group ranches or as hired herdsmen in the private ranches. Family structures and labour demands have rearranged, often resulting in more functionally singleheaded households. While some pastoralists are eager to diversify livelihoods beyond livestock production, others lament the loss of tradition and opportunity to share herding knowledge with their families and children.

More attention is needed regarding costs of these transitions and to opportunities lost, as well as to benefits incurred. As others have noted, conservation can 'succeed' even if local communities are not involved or if they oppose conservation altogether (Brockington 2004); moreover, even if conservation succeeds in involving communities, community empowerment does not necessarily result in community development. In Laikipia, there is evidence of conservation 'success' dealt through seemingly benign conservation and development efforts. Local communities do not unanimously oppose the conservation project or its attempts to support local livelihoods, and many pastoralists involved in this study reported that they will continue to work as hired herders in ranches that prioritize conservation goals alongside livestock production. But the techno-managerial framework framing these efforts does not always include pastoralists as active participants in its efforts. Employing professional male pastoralists in Laikipia does not amount to valuing or incorporating pastoralists' extensive environmental knowledge, especially when management decisions are circumscribed by rigid management institutions with specific technical goals and protocols. At the same time, pastoralists' needs or desires in the 
region are less acknowledged than they could be while they are coerced to negotiate and re-negotiate their livelihoods in particular ways.

This case study has reported on pastoralists' perceptions of, and experiences with, livelihood transitions in Laikipia. Livelihood transitions and their implications are important for the ranches in question, but as many ranches in the region follow very similar top-down management structures for hired herders, other pastoralists may be experiencing similar transitions elsewhere. Participant observation throughout Laikipia and interviews with key informants indeed suggest that these transitions are not at all unique to the ranches involved in this study. More research is needed on the trends toward hired herding labour within the context of broader conservation and development goals in Laikipia and elsewhere.

Moving forward, landowners and land managers independently and collectively must consider how particular types of land management, livestock management, and conservation efforts are framing, supporting, and changing pastoral livelihoods - for better or for worse. Moreover, these transitions should be considered in order to further conservation goals. In this case study, for example, herders reported little incentive to maximize herding effort or to build skills for landscapespecific herding jobs. As quality of herding labour has been linked to both livestock production and rangeland health, landowners and land managers could consider instituting employee benefits such as offering stock in small herds. At worst, these policy shifts will not undermine other ongoing efforts. At best, they could contribute to individual and regional goals of sustaining grasslands for livestock and wildlife alike. As other scholars have noted, it is important for development interventions to encourage livelihood activities that complement pastoralism (Opiyo et al. 2015; Watete et al. 2016). Landowners and land managers at private ranches should actively consider whether they are engaging pastoralists in professional herding jobs in a way that encourages or prohibits them from supporting their own livestock in group ranches. Additionally, more research is needed on long-term implications for herders who have given up livestock entirely in favour of wage work such as professional herding jobs.

Given these complexities, some caution is warranted for Laikipia and for other regions looking to duplicate integrative efforts, especially as conservation increasingly expands beyond protected area boundaries. More research is needed on how pastoralists individually and collectively interact with and negotiate hybrid forms of conservation efforts, especially in rangelands where wildlife, livestock, and humans frequently overlap and share resources. In addition to community group ranches, household and intra-household relations are key to understanding the complexity of conservation outcomes across multiple levels. While scholars and practitioners have long contended that pastoralism can be compatible with wildlife, landowners and land users of both private and community group ranches need to be meaningfully incorporated into planning and management for the efforts to be sustainable. Pastoralists' knowledge and expertise can be instrumental in rangeland management goals but only through a careful and deliberate collective vision.

\begin{abstract}
Acknowledgements
Research informing this article was supported by the University of Michigan's Department (formerly Center) of Afroamerican and African Studies, the Graham Sustainability Institute, the International Institute, the Rackham Graduate School, and the School of Natural Resources and Environment. This study benefited considerably from the guidance of Arun Agrawal, Rebecca Hardin, and Johannes Foufopoulos and from advice by Bilal Butt. Walker DePuy and Colin Donihue were integral to fieldwork logistics, and Nathan Clay provided invaluable insights on the research and this article. Encouragement and support from Brian King greatly assisted in this article's completion. The author is grateful to John Ntirikia and the entire staff of MRC as well as John Ponoto and Samuel Mosiany for their assistance in this research. Most of all, thanks to the many people in Laikipia who participated in this study. Lastly, helpful comments from two anonymous reviewers and the editor helped to improve this article.
\end{abstract}

Competing interests

The author declares that she has no competing interests.

\section{Publisher's Note}

Springer Nature remains neutral with regard to jurisdictional claims in published maps and institutional affiliations.

Received: 1 December 2016 Accepted: 28 February 2017

Published online: 19 June 2017

\section{References}

Agrawal, A. 1995. Dismantling the divide between indigenous and scientific knowledge. Development and Change 26(3): 413-439.

Armitage, D., R. de Loë, and R. Plummer. 2012. Environmental governance and its implications for conservation practice. Conservation Letters 5: 245-255.

Bassett, T.J. 2009. Mobile pastoralism on the brink of land privatization in Northern Côte d'Ivoire. Geoforum 40: 756-766.

Bond, J. 2014a. Conflict, development and security at the agro-pastoral-wildlife nexus: A case of Laikipia County, Kenya. The Journal of Development Studies 50(7): 991-1008.

Bond, J. 2014b. A holistic approach to natural resource conflict: The case of Laikipia County, Kenya. Journal of Rural Studies 34: 117-127.

Boone, R.B. 2005. Quantifying changes in vegetation in shrinking grazing areas in Africa. Conservation and Society 3(1): 150-173.

Bray, D.B., and A. Velázquez. 2009. From displacement-based conservation to place-based conservation. Conservation and Society 7(1): 11-14.

Brockington, D. 2004. Community conservation, inequality and injustice: Myths of power in protected area management. Conservation and Society 2(2): 411-432.

Butt, B. 2011. Coping with uncertainty and variability: The influence of protected areas on pastoral herding strategies in East Africa. Human Ecology 39(3): 289-307.

Butt, B., and M.D. Turner. 2012. Clarifying competition: The case of wildlife and pastoral livestock in East Africa. Pastoralism: Research, Policy and Practice 2(9): 1-15.

Butt, B., A. Shortridge, and A.M.G.A. WinklerPrins. 2009. Pastoral herd management, drought coping strategies, and cattle mobility in Southern Kenya. Annals of the Association of American Geographers 99(2): 309-334.

Carey Jones, N.S. 1965. The decolonization of the White Highlands of Kenya. The Geographical Journal 131(2): 186-201. 
Cleaver, F., T. Franks, F. Maganga, and K. Hall. 2013. Institutions, security, and pastoralism: Exploring the limits of hybridity. African Studies Review 56(3): 165-189.

Cronk, L. 2004. From Mukogodo to Maasai: Ethnicity and cultural change in Kenya. Boulder: Westview Press

Davies, J. 2008. Turning the tide: Enabling sustainable development for Africa's mobile pastoralists. Natural Resources Forum 32: 175-184.

Elhadi, Y.A., D.M. Nyariki, and O.V. Wasonga. 2015. Role of camel milk in pastoral livelihoods in Kenya: Contribution to household diet and income. Pastoralism: Research, Policy and Practice 5(8): 1-8.

Evans, L.A., and W.M. Adams. 2016. Fencing elephants: The hidden politics of wildlife fencing in Laikipia, Kenya. Land Use Policy 51: 215-228.

Fratkin, E. 1997. Pastoralism: Governance and development issues. Annual Review of Anthropology 26: 235-261.

Gadd, M.E. 2005. Conservation outside of parks: Attitudes of local people in Laikipia, Kenya. Environmental Conservation 32(1): 50-63.

Galaty, J. 1993. Maasai expansion and the new East African pastoralism. In Being Maasai: Ethnicity and identity in East Africa, ed. T. Spear and R. Waller, 61-86. Athens: Ohio University Press.

Galaty, J. 1994. Ha(l)ving land in common: The subdivision of Maasai group ranches in Kenya. Nomadic Peoples 34(35): 109-122.

Galvin, K.A. 2009. Transitions: Pastoralists living with change. Annual Review of Anthropology 38: 185-198.

Georgiadis, N.J., J.G. Nasser Olwero, G. Ojwang, and S.S. Romañach. 2007. Savanna herbivore dynamics in a livestock-dominated landscape: I. Dependence on land use, rainfall, density, and time. Biological Conservation 137: 461-472.

Goldman, M. 2003. Partitioned nature, privileged knowledge: Community-based conservation in Tanzania. Development and Change 34(5): 833-862.

Goldman, M., and F. Riosmena. 2013. Adaptive capacity in Tanzanian Maasailand: Changing strategies to cope with drought in fragmented landscapes. Global Environmental Change 23: 588-597.

Graham, M.D., B. Notter, W.M. Adams, P.C. Lee, and T.N. Ochieng. 2010. Patterns of crop-raiding by elephants, Loxodonta africana, in Laikipia, Kenya, and the management of human-elephant conflict. Systematics and Biodiversity 8(4): 435-445.

Greiner, C. 2012. Unexpected consequences: Wildlife conservation and territorial conflict in northern Kenya. Human Ecology 40: 415-425.

Hardin, R. 2011. Collective contradictions of 'corporate' environmental conservation. Focaal--Journal of Global and Historical Anthropology 60: 47-60.

Homewood, K.M., and W.A. Rodgers. 1984. Pastoralism and conservation. Human Ecology 12(4): 431-441.

Homewood, K.M., P.C. Trench, and D. Brockington. 2012. Pastoralist livelihoods and wildlife revenues in East Africa: A case for coexistence? Pastoralism: Research, Policy and Practice 2(19): 1-23.

Huho, J.M., J.K.W. Ngaira, and H.O. Ogindo. 2010. Drought severity and their effects on rural livelihoods in Laikipia district, Kenya. Journal of Geography and Regional Planning 3(3): 035-043.

Igoe, J., and B. Croucher. 2007. Conservation, commerce, and communities: The story of community-based Wildlife Management Areas in Tanzania's northern tourist circuit. Conservation and Society 5(4): 534-561.

Kabiri, N. 2010. The political economy of wildlife conservation and decline in Kenya. The Journal of Environment and Development 19(4): 424-445.

Karmebäck, V.N., J.N. Wairore, M. Jirström, and G. Nyberg. 2015. Assessing gender roles in a changing landscape: Diversified agro-pastoralism in drylands of West Pokot, Kenya. Pastoralism: Research, Policy and Practice 5(21): 1-8.

Kaye-Zwiebel, E., and E. King. 2014. Kenyan pastoralist societies in transition: Varying perceptions of the value of ecosystem services. Ecology and Society 19(3): 17. 1-19.

Kibet, S., M. Nyangito, L. MacOpiyo, and D. Kenfack. 2016. Tracing innovation pathways in the management of natural and social capital on Laikipia Maasai Group Ranches, Kenya. Pastoralism: Research, Policy and Practice 6(16): 1-13.

King, B. 2009. Conservation geographies in sub-Saharan Africa: The politics of national parks, community conservation and peace parks. Geography Compass 3: 1-14.

Kinnaird, M.F., and T.G. O'Brien. 2012. Effects of private-land use, livestock management, and human tolerance on diversity, distribution, and abundance of large African mammals. Conservation Biology 26(6): 1026-1039.

LaRocque, O. 2014. Revisiting distinctions between ranching and pastoralism: A matter of interspecies relations between livestock, people, and predators. Critique of Anthropology 34(1): 73-93.

Lemos, M.C., and A. Agrawal. 2006. Environmental governance. Annual Review of Environment and Resources 31: 297-325.
LWF (Laikipia Wildlife Forum). 2016. Our history. http://www.laikipia.org/about-us/. Accessed on 9 May 2016.

McCabe, J.T. 2003. Sustainability and livelihood diversification among the Maasai of Northern Tanzania. Human Organization 62(2): 100-111.

McCabe, J.T., N.M. Smith, P.W. Leslie, and A.L. Telligman. 2014. Livelihood diversification through migration among a pastoral people: Contrasting case studies of Maasai in Northern Tanzania. Human Organization 73(4): 389-400.

Morgan, W.T.W. 1963. The 'White Highlands' of Kenya. The Geographical Journal 129(2): $140-155$.

Mwangi, E. 2007. Subdividing the commons: Distributional conflict in the transition from collective to individual property rights in Kenya's Maasailand. World Development 35(5): 815-834.

Noe, C., and R.Y.M. Kangalawe. 2015. Wildlife protection, community participation in conservation, and (dis) empowerment in southern Tanzania. Conservation and Society 13(3): 244-253.

Northern Rangelands Trust (NRT). 2016. Naibunga Conservancy Trust. http://www.nrt-kenya.org/naibunga/. Accessed on 30 Mar 2016.

Norton-Griffiths, M. 1996. Property rights and the marginal wildebeest: An economic analysis of wildlife conservation options in Kenya. Biodiversity and Conservation 5: 1557-1577.

Notenbaert, A.M.O., J. Davies, J.D. Leeuw, M. Said, M. Herrero, P. Manzano, M. Waithaka, et al. 2012. Policies in support of pastoralism and biodiversity in the heterogeneous drylands of East Africa. Pastoralism: Research, Policy and Practice 2(14): 1-17.

Opiyo, F., O. Wasonga, M. Nyangito, J. Schilling, and R. Munang. 2015. Drought adaptation and coping strategies among the Turkana pastoralists of northern Kenya. International Journal of Disaster Risk Science 6(3): 295-309.

Prins, H.H.T. 1992. The pastoral road to extinction: Competition between wildlife and traditional pastoralism in East Africa. Environmental Conservation 19(2): 117-123.

Reid, R.S., D. Nkedianye, M.Y. Said, D. Kaelo, M. Neselle, O. Makui, L. Onetu, et al. 2009. Evolution of models to support community and policy action with science: Balancing pastoral livelihoods and wildlife conservation in savannas of East Africa. Proceedings of the National Academy of Sciences 113(17): 4579-4584.

Riginos, C., L.M. Porensky, K.E. Veblen, W.O. Odadi, R.L. Sensenig, D. Kimuyu, F. Keesing, et al. 2012. Lessons on the relationship between livestock husbandry and biodiversity from the Kenya Long-term Exclosure Experiment (KLEE). Pastoralism: Research, Policy and Practice 2(10): 1-22.

Sifuna, N. 2010. Wildlife damage and its impact on public attitudes towards conservation: A comparative study of Kenya and Botswana, with particular reference to Kenya's Laikipia region and Botswana's Okavango Delta region. Journal of Asian and African Studies 45(3): 274-296.

Sundaresan, S.R., and C. Riginos. 2010. Lessons learned from biodiversity conservation in the private lands of Laikipia, Kenya. Great Plains Research 20(1): 17-27.

Thouless, C.R., and J. Sakwa. 1995. Shocking elephants: Fences and crop raiders in Laikipia District, Kenya. Biological Conservation 72: 99-107.

Turner, M.D. 1999. Labor process and the environment: The effects of labor availability and compensation on the quality of herding in the Sahel. Human Ecology 27(2): 267-296.

Turner, M.D. 2009. Capital on the move: The changing relation between livestock and labor in Mali, West Africa. Geoforum 40: 746-755.

Turner, M.D., and P. Hiernaux. 2008. Changing access to labor, pastures, and knowledge: The extensification of grazing management in Sudano-Sahelian West Africa. Human Ecology 36: 59-80.

Waller, R. 2012. Pastoral production in colonial Kenya: Lessons from the past? African Studies Review 55(2): 1-27.

Wambuguh, O. 2007. Interactions between humans and wildlife: Landowner experiences regarding wildlife damage, ownership and benefits in Laikipia District, Kenya. Conservation and Society 5(3): 408-428.

Watete, P.W., W.K. Makau, J.T. Njoka, L. AderoMacOpiyo, and S.M. Mureithi. 2016. Are there options outside livestock economy? Diversification among households of northern Kenya. Pastoralism: Research, Policy and Practice 6(3): 1-13.

Western, D., R. Groom, and J. Worden. 2009. The impact of subdivision and sedentarization of pastoral lands on wildlife in an African savanna ecosystem. Biological Conservation 142: 2538-2546.

Woodroffe, R., P. Lindsey, S. Romañach, A. Stein, and S.M.K. ole Ranah. 2005. Livestock predation by endangered African wild dogs (Lycaon pictus) in northern Kenya. Biological Conservation 124: 225-234.

Young, T.P., T.M. Palmer, and M.E. Gadd. 2005. Competition and compensation among cattle, zebras, and elephants in a semi-arid savanna in Laikipia, Kenya. Biological Conservation 122: 351-359. 